\title{
Neuroprotective Effect of a CNTF-Expressing Lentiviral Vector in the Quinolinic Acid Rat Model of Huntington's Disease
}

\author{
L. Pereira de Almeida, ${ }^{*+}$ D. Zala,* P. Aebischer, ${ }^{*}+\neq$ \\ and N. Déglon* \\ *Division of Surgical Research and Gene Therapy Center, Lausanne Medical School, \\ Switzerland; ${ }^{\dagger}$ Laboratory of Pharmaceutical Technology, Faculty of Pharmacy and \\ Center for Neuroscience, University of Coimbra, Portugal; and ${ }^{\ddagger}$ Swiss Federal \\ Institute of Technology, EPFL, Lausanne, Switzerland
}

Received October 3, 2000; revised J anuary 3, 2001; accepted J anuary 25, 2001; published online May 3, 2001

\begin{abstract}
Neurodegenerative diseases represent promising targets for gene therapy approaches provided effective transfer vectors. In the present study, we evaluated the effectiveness of LacZ-expressing lentiviral vectors with two different internal promoters, the mouse phosphoglycerate kinase 1 (PGK) and cytomegalovirus (CMV), to infect striatal cells. The intrastriatal injection of lenti- $\beta$-Gal vectors lead to 207, $400 \pm 11,500$ and 303,100 \pm 4,300 infected cells in adult rats, respectively. Importantly, the $\beta$-galactosidase activity was higher in striatal extracts from PGK-LacZ-injected animals as compared to CMV-LacZ animals. The efficacy of the system was further examined with a potential therapeutic gene for the treatment of Huntington's disease, the human ciliary neurotrophic factor (C NTF). PGKLacZ- or PGK-CNTF-expressing viruses were stereotaxically injected into the striatum of rats, 3 weeks later the animals were unilaterally lesioned with $180 \mathrm{nmol}$ of quinolinic acid (QA). Control animals displayed $148 \pm 43$ apomorphine-induced rotations ipsilateral to the lesion 5 days postlesion as compared to $\mathbf{2 6} \pm 22$ turns/45 min in the CNTF-treated group. The extent of the striatal damage was significantly diminished in the CNTF-treated rats as indicated by the $52 \pm 9.7 \%$ decrease of the lesion volume and the sparing of DARPP-32, ChAT and NADPH-d neuronal populations. These results further establish that lentiviruses may represent an efficient gene delivery system for the screening of therapeutic molecules in Huntington's disease. 02001 Academic Press

Key Words: Huntington's disease; lentiviral vector; gene therapy; ciliary neurotrophic factor; quinolinic acid lesion model.
\end{abstract}

\section{INTRODUCTION}

Huntington's disease (HD) is an autosomal dominant inherited disorder involving the selective neuronal loss of striatal GABAergic output neurons and astrogliosis (Vonsattel and DiFiglia, 1998). The disease is characterized by motor and cognitive disturbances as well as psychiatric manifestations which usually appear in adult life and progress over one to two decades. Huntingtin, the gene causing Huntington's disease has been cloned in 1993 and the mutation identified as an unstable (CAG)n repeat in the $5^{\prime}$ coding region of the protein (The Huntington's disease collaborative research group, 1993). Despite these important progresses, opening the possibility to generate genetic models of the disease (Mangiarini et al., 1996; Reddy et al., 1998; Hodgson et al., 1999; Schilling et al., 1999; Yamamoto et al., 2000), the mechanisms accounting for the selective striatal degeneration are still largely unknown and there is currently no treatment available.

Several lines of evidence suggest that energetic defects and oxidative damage leading to secondary excitotoxicity and cell death may be implicated in HD process (Beal, 1992; Gu et al., 1996). Consistent with this hypothesis, the intrastriatal injection of the tryp- 
tophan metabolite quinolinate (QA), an N-methyl-daspartate (NMDA) receptor agonist, produces many pathological and neurochemical alterations observed in HD (Beal et al., 1986). The chronic administration of the mitochondrial toxin 3-nitropropionic acid (3-NP) to rats and primates also results in selective striatal lesions (Palfi et al., 1996). These models have been extensively used to develop strategies for the treatment of HD, such as cell replacement and neuroprotective approaches. A significant rescue of degenerating GABAergic neurons was observed following the grafting of fetal striatal cells or the administration of neurotrophic factors in QA-lesioned rats (Nakao et al., 1999; Araujo and Hilt, 1997; Volpe et al., 1998; Bemelmans et al., 1999; Martínez-Serrano and Björklund, 1996; Kordower et al., 1999a). In particular, CNTF initially identified for its ability to sustain the survival of parasympathetic neurons from embryonic chick ciliary ganglia was found to prevent behavioral deficits and striatal degeneration in QA-lesioned rats (Anderson et al., 1996; Emerich et al., 1996, 1997a). This protective effect was further confirmed in the QA and 3-NP primate models of Huntington's disease (Emerich et al., 1997b; Mittoux et al., 2000). In the latter study, the intracerebral and continuous delivery of CNTF at the time of appearance of striatal dysfunction and motor/cognitive deficits in six monkeys chronically treated with 3-NP not only protected neurons from degeneration but also alleviated motor and cognitive symptoms. The therapeutical value of both fetal grafts and CNTF delivery is presently investigated in several clinical trials (Kopyov et al., 1998; St Hillaire et al., 1998; Bachoud-Lévi et al., 1998).

Neuroprotective strategies rely on the development of effective delivery systems leading to robust and long-term expression of the transgene and the presence of the protein in large area of the striatum. The transplantation of genetically engineered cells, the implantation of encapsulated cells releasing neurotrophic factors and more recently in vivo gene therapy approaches with an adenoviral vector have been assessed (Schumacher et al., 1991; Emerich et al., 1996; Bemelmans et al., 1999). In the present study, we have used HIV-1-derived lentiviral vectors that have emerged as a promising gene delivery system in the CNS (Naldini et al., 1996a; Klimatcheva et al., 1999). We have previously demonstrated high and consistent transduction of neuronal cells with a self-inactivating vector (SIN) expressing the LacZ reporter gene in mice, rats, and primates (Bensadoun et al., 2000; Déglon et al., 2000; Kordower et al., 1999b). In addition, the presence of the posttranscriptional element from the woodchuck hepatitis virus (Zufferey et al., 1999) was shown to result in a three- to fourfold increase of the transgene expression level (Déglon et al., 2000), similarly to what was observed in adeno-associated viruses (Loeb et al., 1999; Paterna et al., 2000).

To further optimize and validate this gene transfer system, we have now analyzed the transgene expression levels obtained with two internal promoters: the cytomegalovirus (CMV) and mouse phosphoglycerate kinase 1 (PGK) promoters and assessed the neuroprotective effect of CNTF in the rat QA-lesion model of Huntington's disease.

\section{MATERIALS AND METHODS}

\section{Lentiviral Vector Production}

The cDNA coding for a nuclear-localized $\beta$-galactosidase (LacZ) and the human CNTF cDNA (Aebischer et al., 1996) were cloned in the SIN-W transfer vector (Déglon et al., 2000). Two internal promoters were used: the mouse phosphoglycerate kinase-1 (PGK) and the cytomegalovirus (CMV) promoter. The packaging construct and the vesicular stomatitis virus $G$ protein (VSV-G) envelope used in this study were the pCMVDR-8.92, pRSV-Rev, and the pMD.G plasmids described previously (Naldini et al., 1996a; Dull et al., 1998; Hottinger et al., 2000). The viral particles were produced by transient transfection of 293T cells (Naldini et al., 1996b). Forty-eight hours later the supernatant was collected, filtered and the particle content was determined by an ELISA assay (NEN Life Technologies, Boston, MA). High-titer stocks were obtained by ultracentrifugation. The batches of virus were tested for the absence of replication-competent retroviruses (RCR) (Naldini et al., 1996a). The titers of the LacZ stocks were determined on $293 \mathrm{~T}$ cells. The cells were plated at a density of $2 \times 10^{5}$ cells per well on six-well tissue culture dishes (Costar, Cambridge, MA). Serial dilutions of the viral stocks were added and the number of LacZ-infected cells was analyzed $48 \mathrm{~h}$ later. Titers were calculated by counting the number of blue foci per well and dividing it by the dilution factor. LacZ and CNTF expressing viruses resuspended in phosphate buffered saline (PBS) / 1\% bovine serum albumin (BSA) and matched for particle content $(200,000 \mathrm{ng}$ p24 antigen/ml as measurement by ELISA assay) were used for the in vivo experiments. 


\section{hCNTF ELISA Assay and Bioactivity Measurement}

Quantitative analysis of in vitro and in vivo hCNTF production was performed using an ELISA assay (R\&D Systems, Minneapolis, MN) according to the supplier's manual. 293T cells $\left(1 \times 10^{5}\right)$ were transiently transfected by calcium phosphate precipitation with the CNTF-expressing transfer vector or infected with the SIN-W-PGK-CNTF recombinant virus (p24 = $150 \mathrm{ng} / \mathrm{ml}$ ). Two days later, conditioned media were obtained by incubating the cells in $1 \mathrm{ml}$ of fresh media for $2 \mathrm{~h}$.

The in vivo synthesis of CNTF was determined from punches taken around the injection sites and from the non-injected hemispheres $(n=3)$. The samples were sonicated in $500 \mu \mathrm{l}$ PBS, containing a cocktail of protease inhibitors (pronase, thermolysin, chymotrypsin, trypsin, papain; Roche Pharma, Reinach, Switzerland). The supernatants were used for the ELISA assay.

Choline acetyltransferase activity was determined by measuring the synthesis of $\left[{ }^{3} \mathrm{H}\right]$ acetylcholine from $\left[{ }^{3} \mathrm{H}\right]$ acetylcoenzyme A on E14 rat spinal cord cultures as previously described (Zurn et al., 1994; Zurn and Werren, 1994). Fifty microliters of conditioned media from 293 T cells infected with the SIN-W-PGK-CNTF virus, transfected with the corresponding plasmid or from control cells, were added to the E14 rat spinal cord cultures.

\section{Animals}

Adult female Wistar rats (Iffa-Credo, France), weighing 180-200 $\mathrm{g}$ were used in these studies. The animals were housed in a controlled temperature room that was maintained on a 12-h light/dark cycle. Food and water were available ad libitum. The experiments were carried out in accordance with the European Community Council directive (86/609/EEC) for care and use of laboratory animals.

\section{Injection of the Lentiviruses}

The concentrated viral stocks were defrost and resuspended by repeated pipetting. Two microliters of CNTF or LacZ-expressing lentiviral vectors were injected into the striatum of pentobarbital anesthetized (45 mg/kg, i.p.) animals using a syringe (Hamilton, Reno, NV), with a 28-gauge blunt tip needle. The stereotaxic coordinates for the injection were: 1.2 rostral to bregma; 2.6 lateral to midline for the LacZ experiment or 2.2 for the QA-CNTF experiment; 4.5 ventral from the dural surface; with the mouthbar set at 3.3. The suspension was injected at $0.2 \mu \mathrm{l} / \mathrm{min}$ by means of an automatic injector (Stoelting Co., Wood Dale, U.S.A.) and the needle was left in place for 5 min. The skin was closed using a 6-0 Vicryl suture (Ethicon, Johnson and Johnson, Brussels). The animals were allowed to recover for 3 weeks before the injection of quinolinic acid.

\section{$\boldsymbol{\beta}$-Galactosidase Activity}

One week after the injection of CMV- or PGK-LacZexpressing viruses, the animals were sacrificed, perfused with ice-cold PBS containing $0.02 \%$ ascorbic acid and 5000 units of heparin (Liquemin, Roche, Reinach, Switzerland), and fixed in $4 \%$ paraformaldehyde for $24 \mathrm{~h}$.

$\beta$-Galactosidase activity was detected by incubating sections in PBS containing $4 \mathrm{mM}$ FeCN(II)/FeCN(III), $2 \mathrm{mM} \mathrm{MgCl} 2,0.02 \% \mathrm{NP}-40$, and $0.4 \mathrm{mg} / \mathrm{ml} \mathrm{X-Gal.}$ $\beta$-Galactosidase activities were also measured on a punch made over a 2-mm-thick transversal slices cut with a tissue chopper and covering most of the striatum. The samples were rapidly frozen on dry ice and kept at $-80^{\circ} \mathrm{C}$ until processing. The samples were sonicated (Microson Ultrasonic Cell Disruptor; Heat Systems, Farmingdale, NY; 10s/low power) in $500 \mu \mathrm{l}$ of extraction solution provided with the $\beta$-galactosidase assay kit (Promega, Madison, WI). After centrifugation at $14,000 \mathrm{rpm}$ for $10 \mathrm{~min}$ the supernatants were assayed according to the manufacturer's protocol.

\section{Quinolinic Acid Lesion}

Quinolinic acid (QA) (Sigma Chemical, St. Louis, $\mathrm{MO}$ ) was dissolved in $2 \mathrm{M} \mathrm{NaOH}$, the $\mathrm{pH}$ was adjusted to 7.4 and the volume completed with PBS, $\mathrm{pH}$ 7.4. Under pentobarbital anesthesia $(45 \mathrm{mg} / \mathrm{kg})$, the animals received an intrastriatal injection of $1 \mu \mathrm{l}$ of quinolinic acid (180 nmol) using the following coordinates: 1.2 rostral to bregma; 3.2 lateral to midline; 4.5 ventral from the dural surface; with the mouthbar set at 3.3. The toxin was injected over $1 \mathrm{~min}$, and the needle was left in place for an additional $3 \mathrm{~min}$.

\section{Behavioral Analysis}

Apomorphine-induced rotational asymmetry was measured twice before the injection of the virus. Animals were injected subcutaneously with $1.0 \mathrm{mg} / \mathrm{kg}$ apomorphine (Amino AG, Neunhof, Switzerland) and placed into a test chamber (Rotoscan, Rotometer v5.06, Omnitech Instruments, Columbus, $\mathrm{OH}$ ) for a 3-min 
habituation period before a 45-min test session. Rotations were defined as complete $360^{\circ}$ ipsilateral turns and were reported as the net difference between the two directions. Animals that did not display spontaneous turning behavior (less than 20 tours per $45 \mathrm{~min}$ ) were selected. The animals were tested 1 and 2 weeks after the injection of the virus and 5, 9, and 13 days after QA administration. Results are expressed as the net difference between the total number of turns after and before the administration of QA. Ipsilateral turns were counted as positive turns, whereas contralateral turns were counted as negative turns.

\section{Histological Processing}

Two weeks after QA lesion, the animals were sacrificed and the brains processed for immunohistochemistry. The animals were anesthetized with a sodium pentobarbital overdose, transcardially perfused with heparinized PBS, and postfixed in $4 \%$ paraformaldehyde for approximately $24 \mathrm{~h}$ and finally cryoprotected in $25 \%$ sucrose $/ 0.1 \mathrm{M}$ phosphate buffer for $48 \mathrm{~h}$. The brains were frozen in dry ice and coronal sections were cut on a sliding cryostat microtome (Cryocut 1800, Leica Microsystems, Nußloch, Germany) at a temperature of $-20^{\circ} \mathrm{C}$ and a thickness of $25 \mu \mathrm{m}$. The slices throughout the striatum were collected and stored in 48-well trays (Costar, Cambridge, MA) as free-floating sections in PBS containing $0.12 \mu \mathrm{M}$ sodium azide. The trays were stored at $4^{\circ} \mathrm{C}$ until immunohistochemical processing. A rabbit polyclonal anti- $\beta$-galactosidase antibody was used for $\beta$-Gal staining (1:500, 5 Prime 3 Prime Inc., U.S.A.). To identify the type of infected cells, double-staining were performed with the neuronal marker NeuN (1:200: Chemicon, Temecula, CA) and the glial cell marker glial fibrillary acidic protein (1:50: GFAP) (Roche Pharma, Reinach, Switzerland). The mounted sections were analyzed by confocal scanning laser microscopy (Leica TCSNT, argon-Krypton laser). Fluorescent signals were collected, digitally color enhanced, and superimposed.

The evaluation of the lesion volume and the quantification of the cell loss was performed on six sections separated by $200 \mu \mathrm{m}$. These samples were processed by immunohistochemistry for glutamic acid decarboxylase $67\left(\mathrm{GAD}_{67}\right)$ (Chemicon, Temecula, $\left.\mathrm{CA}\right)$, choline acetyltransferase (ChAT) (Roche Pharma, Reinach, Switzerland), dopamine and cAMP-regulated phosphoprotein of a molecular mass of $32 \mathrm{kDa}$ (DARPP-32) (a generous gift from Dr. Greengard, Rockefeller Univ., NY), and neuronal nitric oxide synthase
(nNOS) (Chemicon International Inc.). Enzymatic staining for NADPH-diaphorase (NADPH-d) was performed as previously described (Ellison et al., 1987). For immunohistochemical stainings, endogenous peroxidase activity was quenched with $0.1 \%$ diphenylhydrazine/PBS $\left(37^{\circ} \mathrm{C} / 30^{\prime}\right)$ and washed three times in PBS. Free floating sections were incubated overnight in 5\% Normal Goat Serum (NGS, Dako Diagnostics, Switzerland)/0.1 M phosphate buffered saline at $4^{\circ} \mathrm{C}$, followed by an overnight reaction (except for GAD, where the sections were incubated for 3 days) with the respective antibodies: $\beta$-Gal (1:500); GAD (1:2000); ChAT (1:50), DARPP-32 (1:20,000), nNOS (1:1000) diluted in PBS/1\% NGS solution. After three washings the sections were incubated with the corresponding biotinylated secondary antibody (Vector, Burlingame, CA; 1:200) for $2 \mathrm{~h}$ at room temperature, and bound antibody was visualized by using the ABC system (Vectastain ABC kit, Vector Laboratories, West Grove, U.S.A.), with 3,3' diaminobenzidin (DAB Metal Concentrate, Pierce, Rockford, IL) as chromogen. The sections were mounted, dehydrated by passing twice through ethanol and toluol and coverslipped with Merckoglas. Secondary antibodies coupled to fluorescent chromophores (Jackson Immunoresearch Laboratories, West Grove) were used for LacZ (1:200: FITCGoat Anti-rabbit), NeuN, and GFAP (1:500: CY3-Goat Anti-mouse). The sections were agitated at a speed of $100 \mathrm{rpm}$ for $2 \mathrm{~h}$ at ambient room temperature and finally mounted on glass slides with FluorSave Reagent (Calbiochem, La Jolla, CA).

\section{Cell Counting and Evaluation of the Lesion Size}

The number of $\beta$-galactosidase-positive nuclei was determined by counting the number of DABstained nuclei on five sections covering the infection site over a $2.4-\mathrm{mm}$ zone using a $20 \times$ objective. The total number of infected neurons was calculated by multiplying the number of sections by the average number of neurons between two sections (Tseng et al., 1998). Counts of DARPP-32-, ChAT-, and NADPH-d-stained neurons were performed using a $20 \times$ objective on six sections adjacent to those analyzed for the lesion size and the values expressed as percentage of the neuron numbers on the nonlesioned side. The total striatal surface areas were considered for ChAT and NADPH-diaphorase countings, while, for DARPP-32, a sampling of the striatum was made by counting neurons on a quadrant placed at the bottom of the ventricle. 
A

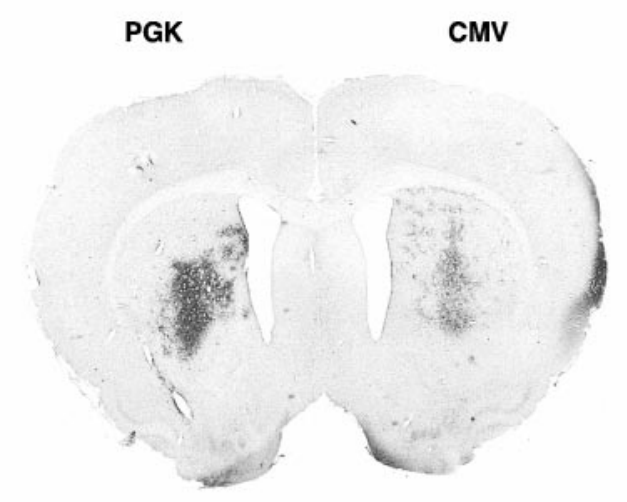

C

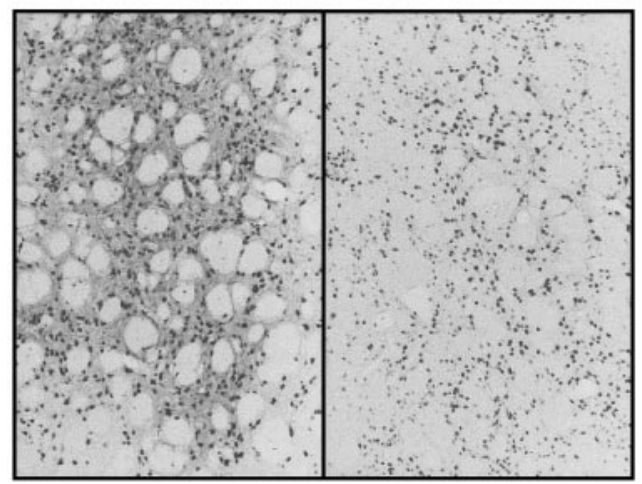

B

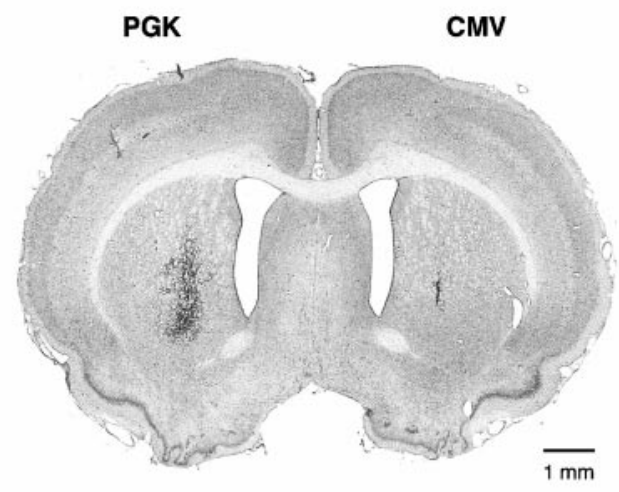

D

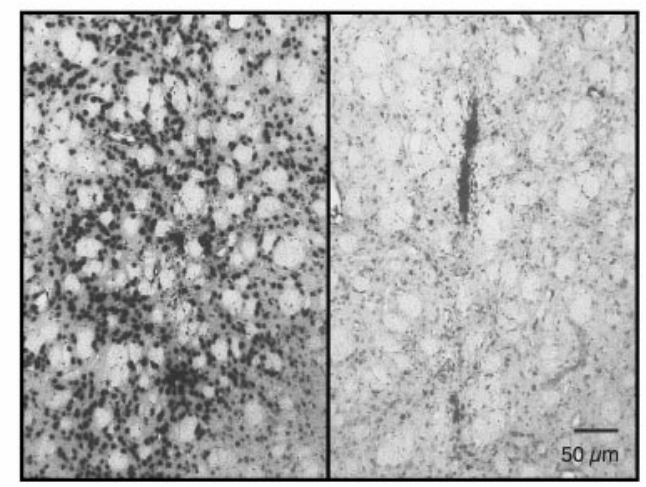

FIG. 1. Rat striatal sections showing LacZ immunoreactivity (A, C) or enzymatic activity (B, D) 1 week after the injection of the SIN-W-PGK and SIN-W-CMV-lentiviral vectors in the left and right hemispheres, respectively. (C, D) High power photomicrographs around the injection site showing the density of neurons infected and the higher LacZ expression level obtained with the SIN-W-PGK lentivirus as compared with the SIN-W-CMV vector.

The extent of the lesion produced by QA was determined by digitizing six sections per animal with a slide scanner and quantifying it with an image analysis public domain program (NIH-Image, Version 1.6.1, National Institutes of Health). The lesion size was determined from equidistant $(200 \mu \mathrm{m})$ GAD-stained sections covering the center of the lesion. The border of the lesion was traced on GAD stained sections throughout the six sections and the corresponding volume of the lesion was determined and expressed as percentage of the total hemisphere volume.

\section{Data Analysis}

Data are expressed as mean \pm SEM and evaluated for analysis of variance (ANOVA) followed by a Scheffe's PLSD post-hoc test (StatView 4.0, Version 3.2.6, Aladdin Systems, U.S.A.). The significance level was set at $P<0.05$.

\section{RESULTS}

\section{Transduction Efficiency and $\boldsymbol{\beta}$-Galactosidase Expression Levels with SIN-W-PGK and SIN-W-CMV Vectors}

To evaluate the transduction efficacy and the level of expression of $\beta$-galactosidase in vivo, $2 \mu \mathrm{l}$ of SINW-PGK- and SIN-W-CMV-LacZ viruses were injected in the left and right hemisphere of three adult Wistar rats. The titers of the concentrated $\beta$-Gal-expressing viruses were $2.6 \times 10^{8}$ and $5.5 \times 10^{8} \mathrm{TU} / \mathrm{ml}$, respectively. The histological analysis of striatal sections collected 1 week later showed that infected cells are present over $2.2 \mathrm{~mm}$ with 207,400 \pm 11,500 and $303,100 \pm 4,300 \beta$-Gal-expressing cells in PGK- and CMV-injected animals (Figs. 1, 2A and 2B). A robust immunostaining of the nucleus and the fibers was observed in PGK-LacZ-infected cells, whereas the la- 
A

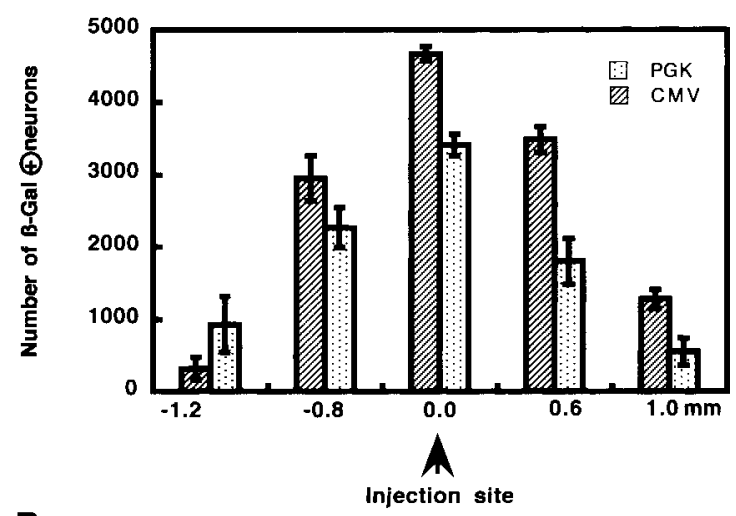

B

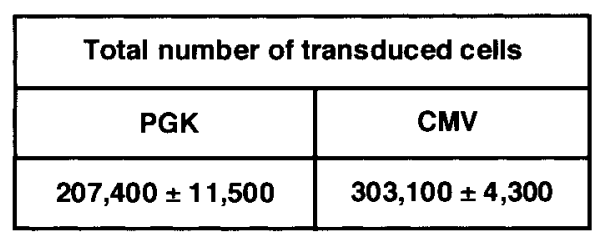

C

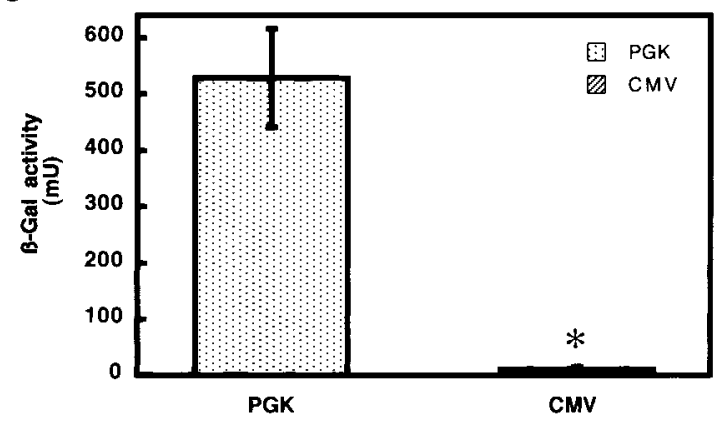

FIG. 2. (A) Evaluation of the diffusion of the lentiviral vector from the injection site and determination of the number of the LacZexpressing cells on five immunostained sections. (B) Estimation of the total number of infected cells in the PGK- and CMV-LacZinjected animals. (C) Measurement of $\beta$-galactosidase activity on striatal punches from PGK- and CMV-LacZ injected animals $(n=5)$. ${ }^{*} P=0.0004$.

beling was limited to the nucleus with the CMV-LacZ vector (Figs. 1A and 1C). Similarly, the X-Gal enzymatic staining was more intense in the PGK-LacZ animals as compared with the CMV-LacZ group (Figs. $1 \mathrm{~B}$ and $1 \mathrm{D})$. To quantify the difference in transgene expression levels, striatal punches covering most of the infected area were used to measure $\beta$-galactosidase enzymatic activity in five additional animals. The activity was higher with the PGK-LacZ virus as compared with the CMV-LacZ virus (Fig. 2C). Control animals or animals injected with PBS did not display $\beta$-galactosidase activity (data not shown). In addition, robust expression of the LacZ reporter gene was observed 12 months after the injection of SIN-W-PGK virus in the striatum of two rats (Fig. 3A). Long-term expression of $\beta$-galactosidase is not associated with neurotoxic effects as indicated by the unaltered expression of the neuronal markers, DARPP-32, ChAT, and nitric oxide synthase (nNOS) (Fig. 3B). These results establish that SIN-W-PGK lentiviral constructs allow the transduction of a large number of cells in the rat striatum and that high and sustained expression of the transgene is obtained with the housekeeping PGK promoter.

\section{Neurotropism of VSV-G Pseudotyped Lentiviruses}

The strong neurotropism observed after the injection of lentiviral vectors in the CNS has been attributed to the VSV-G envelope and/or the preferential activity of the CMV promoter in neurons (Naldini et al., 1996). We therefore analyzed whether the use of the housekeeping promoter PGK alters the phenotype of transduced cells. Striatal sections from the SIN-WCMV- and SIN-W-PGK-injected animals were immunostained with $\beta$-Gal and the NeuN neuronal or GFAP glial markers (Fig. 4). Confocal microscopic images showed that in agreement with previous studies with the CMV-LacZ construct (Naldini et al., 1996b), essentially all $\beta$-Gal-positive cells were NeuN-positive (Fig. 4) with $1.80 \pm 0.75 \%$ of GFAP/LacZ doublelabeled cells. Similar results were obtained with the PGK-driven construct, suggesting that the neurotropism of the lentiviral vector is due to the VSV-G envelope.

\section{Characterization of a CNTF-Encoding Lentivirus}

Based on the above-mentioned data, the cDNA coding for the human CNTF was cloned into the SIN-W-PGK backbone. To evaluate the production of CNTF, 293T cells were infected with the CNTF-lentivirus (p24 = 150 $\mathrm{ng} / \mathrm{ml}$ ). Seventy-two hours later, the levels of CNTF present in the medium were determined by an enzymelinked immunosorbent assay (ELISA). CNTF levels of $84.6 \pm 16.8 \mathrm{ng} \mathrm{CNTF} /$ day were detected in the infected cells, whereas it was undetectable in control cells. The vector was shown to express bioactive CNTF as determined by an increased choline acetyltransferase (ChAT) activity on E14 rat mesencephalic primary cell cultures exposed to conditioned media from transfected or infected 293T cells (Table 1). The in vivo production of CNTF was measured on 3 Wistar rats injected with $2 \mu \mathrm{l}$ of SIN-W-PGK-CNTF virus $(200,000 \mathrm{ng}$ p24/ml). One 
A

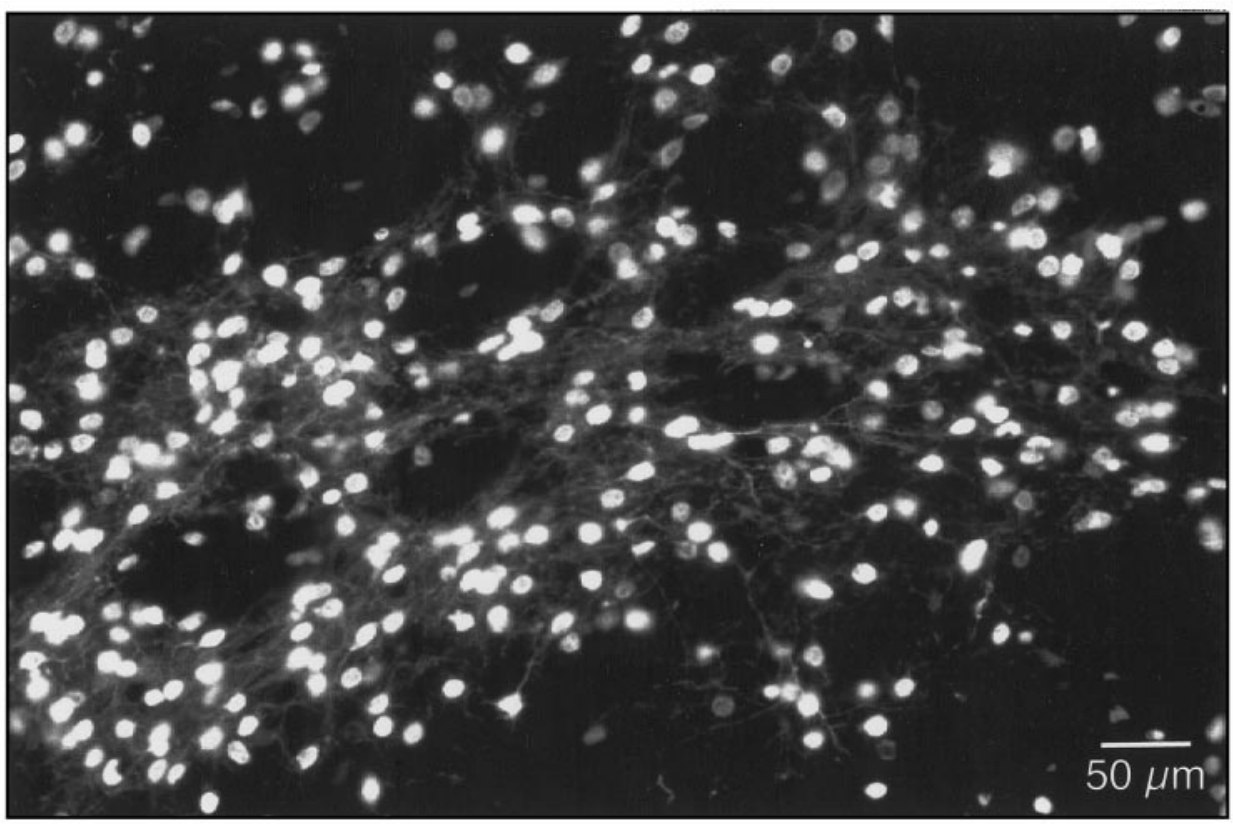

B

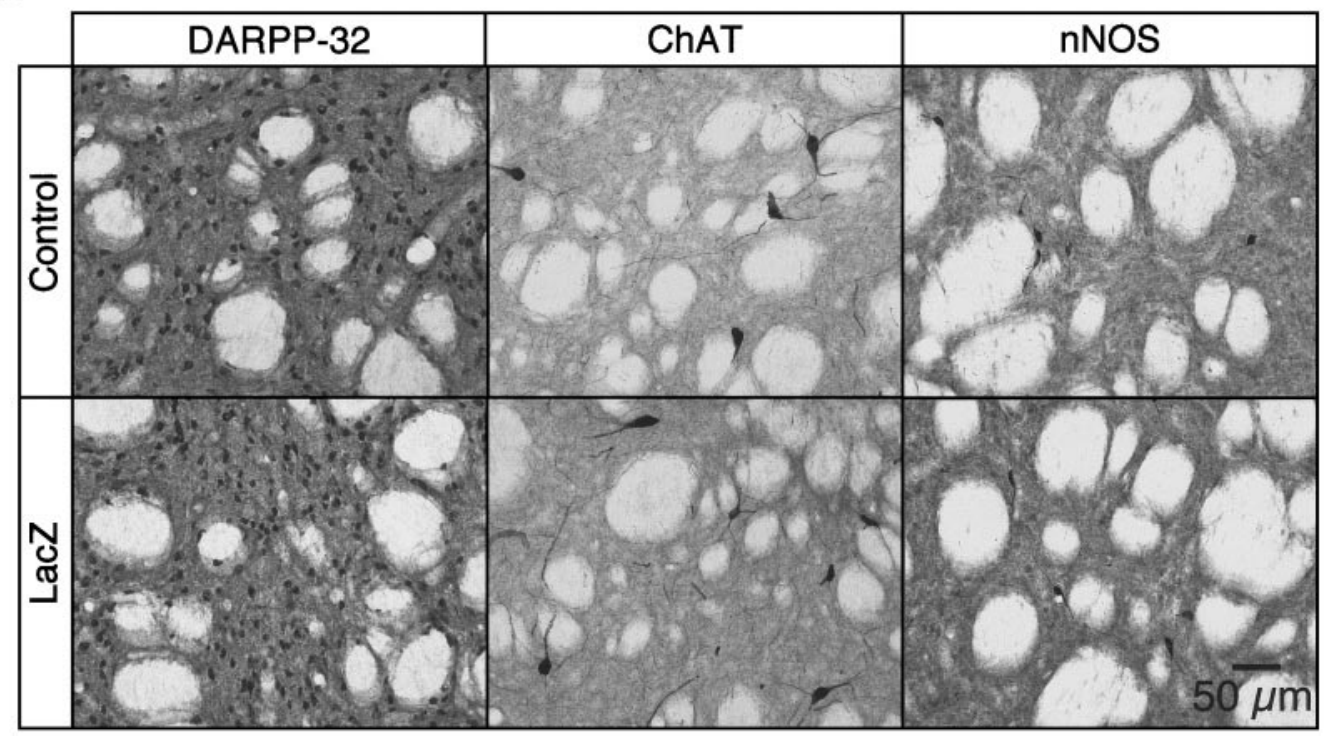

FIG. 3. (A) LacZ-immunostained striatal section showing the robust expression of the reporter gene 12 months postinjection of a SIN-W-PGK lentiviral vector. (B) The expression of the neuronal markers DARPP-32, ChAT, and nNOS were not altered by the long-term and sustained expression of $\beta$-galactosidase.

week later, the animals were sacrificed and a punch covering most of the striatum was excised. The tissue was homogenized and analyzed by ELISA assay for CNTF content. The concentration of CNTF was $0.94 \pm$ $0.33 \mathrm{ng} / \mathrm{mg}$ protein in the injected site, whereas it was undetectable in the noninjected hemispheres.

\section{Neuroprotective Effect of a CNTF-Expressing Lentivirus}

Wistar rats were injected with lentiviruses encoding for CNTF $(n=6)$ or LacZ $(n=6)$. Three weeks later, the animals were lesioned with the intrastriatal injec- 


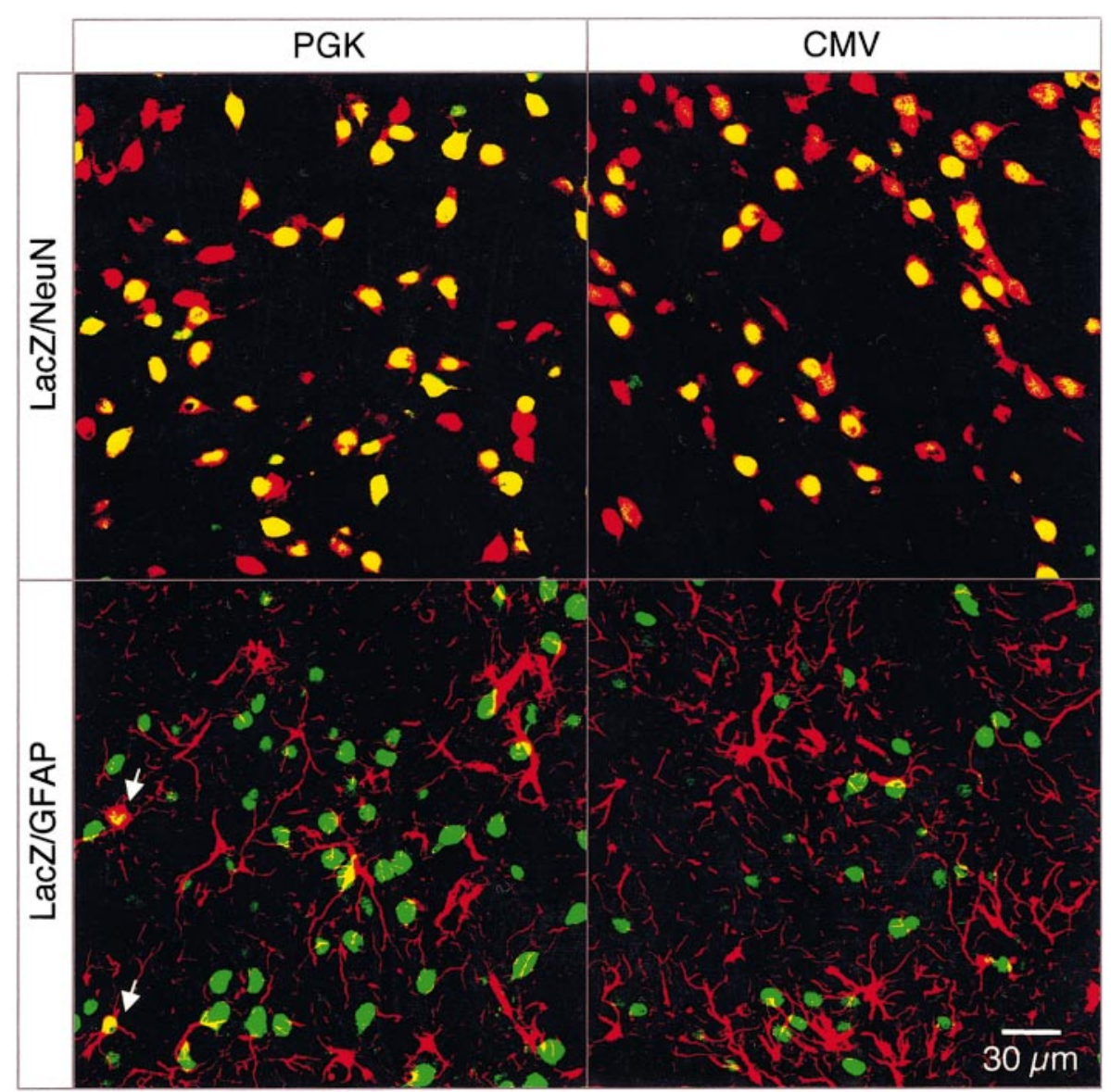

FIG. 4. Confocal microscope images of striatal sections from PGK-LacZ or CMV-LacZ injected rats stained for $\beta$-galactosidase (green) and the neuronal marker NeuN (red) or GFAP (red). Numerous NeuN ${ }^{+}$neurons were infected with the LacZ-expressing lentivirus as indicated by the yellow nuclei resulting from the colocalization of $\beta$-Gal (Green) and NeuN (Red), whereas only scarce $\beta$-Gal-positive cells were double-stained for GFAP (arrows).

tion of 180 nmol QA. The striatal degeneration produced by the unilateral administration of QA resulted in an apomorphine-rotational asymmetry (Borlongan et al., 1995; Nakao and Brundin, 1997). As expected, control animals injected with the LacZ-virus displayed ipsilateral turning in response to the dopamine agonist, 5, 9, and 13 days after QA administration (Fig. 5). In contrast, a significant reduction of the motor deficit was observed in the CNTF-treated animals (Fig. 5). Interestingly, a slower weight gain was observed in the CNTF animals $(11.1 \pm 3.2 \%) 12$ days after QA lesion relative to the control group $(19.5 \pm 1.2 \% ; P=$ 0.0342).

The glutamic acid decarboxylase (GAD) marker of GABAergic neurons, including the projecting neurons that make up for more than $90 \%$ of all striatal neurons was used to measure the damages caused by the in-
TABLE 1

Choline Acetyltransferase Activity Measured on E14 Rat Embryonic Spinal Cord Cultures Exposed to Conditioned Media from 293 T Cells Transfected or Infected with SIN-W-CNTF or from Mock-Infected Cells

\begin{tabular}{lc}
\hline \multicolumn{1}{c}{ Media } & ChAT activity (\%) \\
\hline Control & 100 \\
Mock-infected 293T cells & $116 \pm 15$ \\
10 ng/ml rhCNTF & $286 \pm 4$ \\
293T Transfected: hCNTF transfer vector & $362 \pm 37$ \\
293T Infected: hCNTF lentivirus & $317 \pm 81$ \\
\hline
\end{tabular}

Note. The values are expressed as percentages of control cultures grown in the absence of neurotrophic factor. The addition of 10 $\mathrm{ng} / \mathrm{ml}$ of recombinant hCNTF was used as a positive control. Each value represents the mean of two culture wells from two separate experiments. Data are expressed as the mean \pm SEM. 


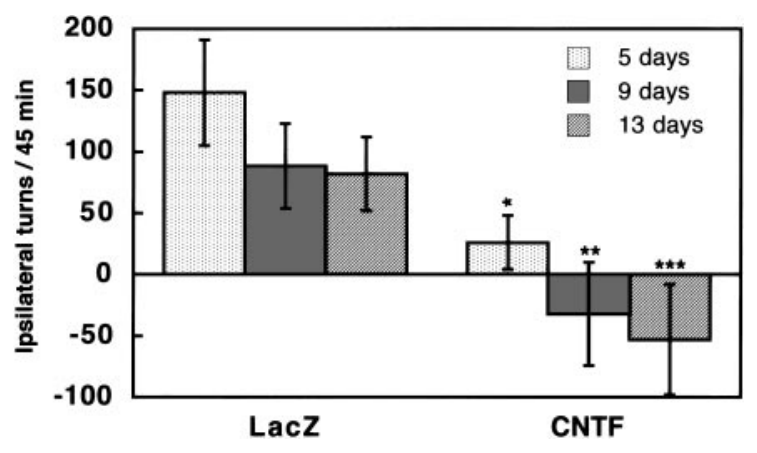

FIG. 5. Histogram showing the average changes in rotational asymmetry induced by apomorphine stimulation $(1 \mathrm{mg} / \mathrm{kg}$, s.q.) 5 , 9, and 13 days after QA lesion. Positive values correspond to turns ipsilateral to the lesion. A significant reduction of the drug-induced rotational behavior was observed in the CNTF-treated animals ( $n=$ $6)$ as compared with the LacZ-injected animals $(n=6)$. Values are expressed as mean \pm SEM. ${ }^{*} P=0.031,{ }^{* *} P=0.051,{ }^{* *} P=0.031$.

jection of QA (Fig. 6). In the LacZ-injected animals, a drastic reduction of the GAD-ir covering most of the striatum and in some cases adjacent regions was observed on the lesioned side. In contrast, the volume of the lesion was significantly reduced in the CNTF treated animals (Fig. 6) $(P=0.0012)$.

The cell degeneration was analyzed in different subpopulations of striatal neurons. The neuronal phosphoprotein DARPP-32 was used as a marker of the projecting GABAergic neurons affected in Huntington's disease. The administration of QA in LacZ-injected animals induced a near complete loss of DARPP-32 staining in the core of the lesion with only $26.2 \pm 6.2 \%$ positive neurons throughout the affected area (Fig. 7). This loss of DARPP-32 immunoreactivity was however attenuated in the CNTF-treated animals compared to the control group $(73.7 \pm 6.9 \%$; $P=$ 0.0004) (Fig. 7).

To further assess the effect of CNTF administration, similar analyses were performed on two populations of interneurons. The cholinergic interneurons visualized with choline acetyltransferase (ChAT) immunostaining and the GABAergic interneurons identified with nicotinamide adenine dinucleotide phosphate diaphorase (NADPH-d). In control animals, the number of ChAT-ir and NADPH-d-ir cells was significantly reduced on the lesioned side (Fig. 7). In CNTF-treated animals, ChAT- and NADPH-d-positive neurons with long neuritic processes were seen even in sections close to the needle tract (Fig. 7). Cell counts further demonstrated that CNTF treatment rescues these two subpopulations of neurons (Fig. 7).

\section{DISCUSSION}

Over the past few years, the major obstacles toward the use of viral vectors for gene therapy applications has been the poor transduction efficiency often associated with transient and low transgene expression levels (Verma and Somia, 1997; Anderson, 1998). Several strategies are currently being investigated to overcome these limitations. Among them, the development of second/third generation of viral vectors (Romano et al., 1999), the use of viruses with altered tropism (Russell and Cosset, 1999), the assessment of transcriptional and posttranscriptional regulatory elements (Walther and Stein, 1996; Srinivasakumar et al., 1997) and the evaluation of methods to improve the transduction and diffusion of viruses in tissues (Ko-

A

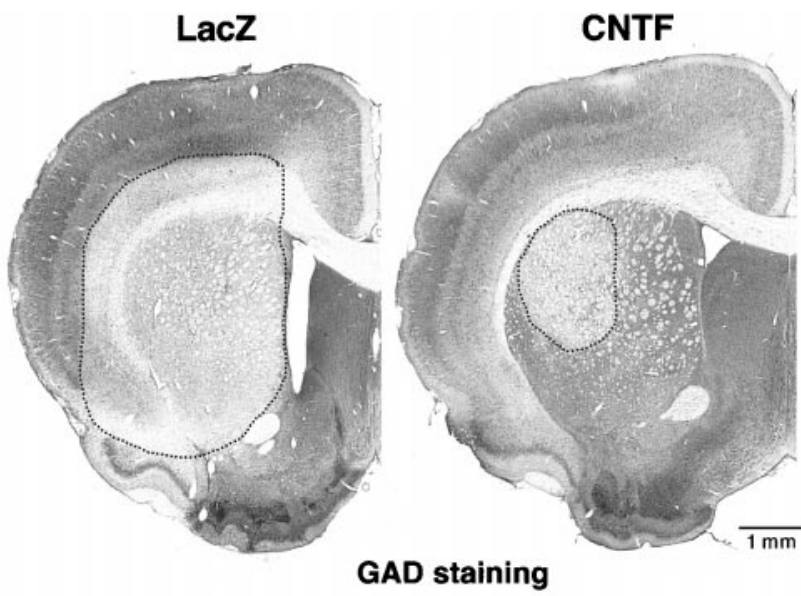

B

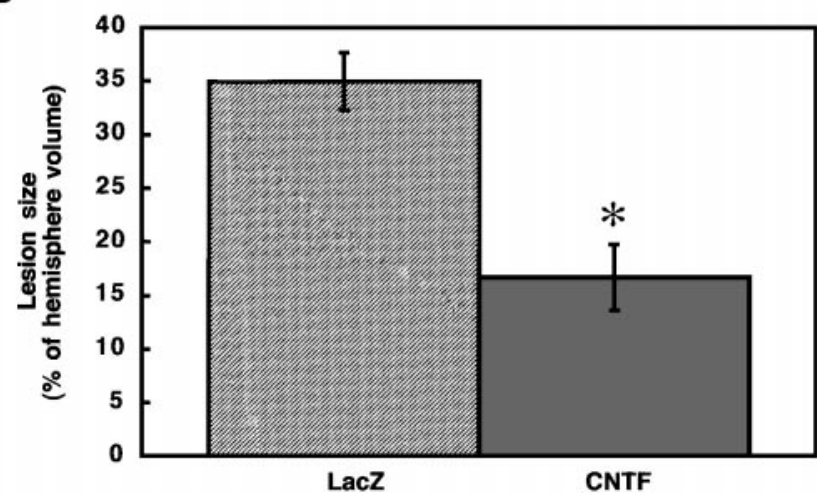

FIG. 6. (A) GAD immunohistochemical staining in the striatum of two rats showing the reduced lesion area in the CNTF-treated animal as compared with the LacZ-injected rat (40 and 7.6\%, respectively). (B) lesion volume in control and CNTF-treated animals expressed as percentage of the hemisphere volume. Values are expressed as mean \pm SEM. ${ }^{*} P=0.0012$. 


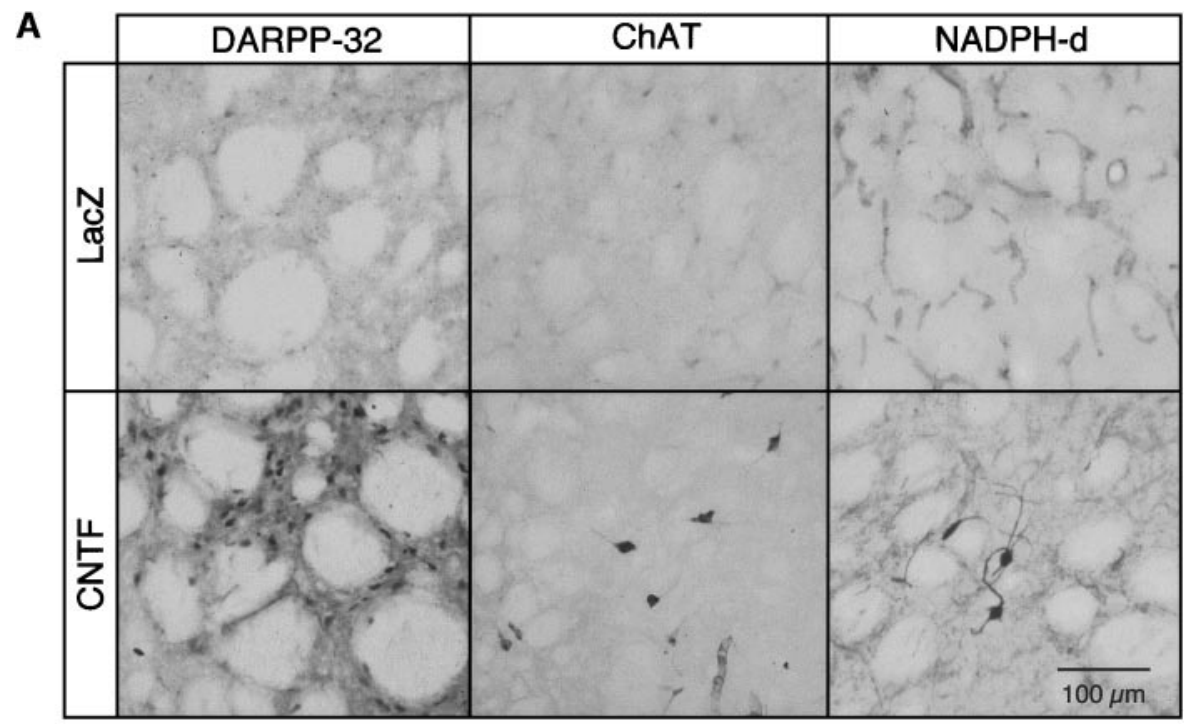

B

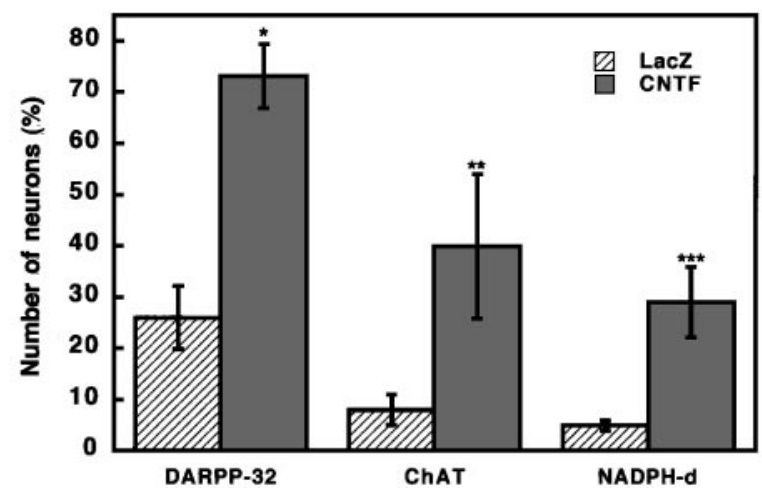

FIG. 7. (A) Micrographs showing DARPP-32, ChAT, and NADPH-d histochemical stainings in the striatum 2 weeks after QA lesion in animals injected with lentiviruses expressing $\beta$-Gal or CNTF. (B) Percentage of DARPP-32, ChAT, or NADPH-d-positive neurons on the right (lesioned) side versus left (nonlesioned) side. Values are expressed as mean \pm SEM. ${ }^{*} P=0.0004,{ }^{* *} P=0.0613,{ }^{* * *} P=0.0064$.

hutnicka et al., 1999; Tenenbaum et al., 1999; Zennou et al., 2000).

In this context, lentiviral vectors from human, simian, feline, or equine origin appear as promising gene delivery vehicles for quiescent cells such as neurons and hematopoietic stem cells (Poeschla et al., 1998; White et al., 1999; Johnston and Power, 1999; Olsen, 1998). This property might however not apply to all postmitotic cells as suggested by the cell-cycle dependent transduction of hepatocytes (Park et al., 2000) and the low transduction efficiency of muscle (Trono, 2000). In the CNS, high transduction efficiency and long-term expression of reporter genes have been reported (Naldini et al., 1996b; Blömer et al., 1997; Déglon et al., 2000). In the present study, $2-3 \times 10^{5}$ infected cells spread over $2.2 \mathrm{~mm}$ were counted after the injection of $2 \mu \mathrm{l}$ of concentrated stock of LacZ- expressing viruses. The increased number of infected cells in the CMV-W-LacZ-injected hemispheres $\left(303,100 \pm 4,300^{\prime}\right)$ as compared to the PGK-W-LacZ $(207,400 \pm 11,500)$ correlates with the higher titer of the latter batch $\left(5.5 \times 10^{8}\right.$ and $2.6 \times 10^{8} \mathrm{TU} / \mathrm{ml}$, respectively). Compared to earlier studies, this represents a 10- to 30-fold increase in the number of infected striatal cells $\left(1-2 \times 10^{4}\right.$ transduced cells) (Zufferey et al., 1997; Mitrophanous et al., 1999). The higher proportion of transduced cells might be due to differences in vector design, in target cells, and protocols used to determine the titers, in the procedures utilized to concentrate the viral stocks and/or in the methods employed to detect infected cells. Storage conditions aimed at minimizing the development of aggregates and noninfectious particles, as well as injection procedures insuring an optimal diffusion of the 
viral particles may also explain the increased transduction efficiency. The importance of these parameters remains to be established.

In agreement with previous reports, the great majority of the transduced cells express the neuronal marker NeuN (Naldini et al., 1996; Blömer et al., 1997). If one considers that the striatum of rats contains approximately 2.8 million neurons (Oorschot, 1996), a single injection of a lentiviral vector is therefore sufficient to infect approximately $10 \%$ of the striatal neurons. Increasing the amount of viral particles, the number of sites and/or improving the vector properties (Zennou et al., 2000) may further augment this proportion. This will be particularly important for the scale-up of the technology in primates (Kordower et al., 1999b) and for the expression of intracellular proteins.

To maximize the transgene expression and avoid the transcriptional shut off over time, the appropriate promoter/enhancer combination has to be determined for each cell type. Lentiviral vectors expressing the LacZ reporter under the control of the CMV or the mouse PGK promoters were therefore compared. Similarly to what has been observed on purified motoneurons infected with LacZ-expressing lentiviral vectors in vitro (Cisterni et al., 2000), higher $\beta$-gal activity was measured on striatal punches from PGK-LacZ-injected animals. A result which can't be explained by differences in viral titers or variability in the number of infected cells between the two groups.

As a first step toward the use of lentiviral vector as gene delivery system in $\mathrm{HD}$, we have produced a lentivirus encoding the human CNTF. The administration of this molecule in a large brain structure, such as the striatum and the short half-life of the protein represent a major challenge for its clinical application. The diffusion of lentiviral vectors several millimeters from the injection site may overcome these limitations and provide multiple point sources of CNTF throughout the striatum, ensuring an optimal diffusion of the protein and maximizing its biological activity.

Previous studies have shown that the intracerebral administration of recombinant CNTF with minipumps or the implantation of encapsulated CNTF-releasing cells, 3 to 12 days prior to lesioning with QA, protect rat striatal neurons and prevent motor and cognitive deficits (Anderson et al., 1996; Emerich et al., 1997a). Although differences in the QA lesioning protocol and in the evaluation methods preclude any direct comparison with previous reports, our results demonstrated that the injection of a CNTF-expressing lentiviral vector and the continuous production of nanogram of CNTF partially reversed behavioral deficits. A number of factors can influence apomorphine-induced rotational behavior in QA-lesioned rats. Among them, the extent and localization of the lesion (Nakao and Brundin, 1997; Fricker et al., 1996), the interval between the administration of QA and the behavioral analysis, and the interval between successive drug administration. Differences in these parameters may explain the observed decrease in rotational asymmetry over time contrary to what has been described by Nakao et al. (1996). These behavioral improvements were associated with a rescue of GAD, DARPP32, ChAT, and NADPH-d-ir neurons in CNTF-treated animals. The mechanism of action of CNTF is however unclear. CNTF may directly interfere with the toxic effect of QA by altering the expression or function of glutamate receptors. This possibility seems unlikely as CNTF does not block the neurotoxic effect of glutamate in vitro (Mattson et al., 1995) and prevents striatal degeneration of 3-NP-lesioned animals (Mittoux et al., 2000). Striatal neurons are responsive to the cytokine (Buzas et al., 1999) and brain injury leads to an up-regulation of CNTF and CNTFR $\alpha$ mRNAs in the wound area that correlates with the appearance of reactive astrocytes (Ip et al. 1993; Asada et al. 1995). CNTF activates the JAK-STAT signal transduction pathway (Hirano et al., 1994; Bonni et al., 1997) and induces the expression of immediate early genes (Bonni et al., 1993; Gloaguen et al., 1997). The development of microarray technology (Serafini, 1999) should offer new opportunities to dissect the intracellular signaling pathway and neuroprotective effect of CNTF and obtain a global view of the temporal program of gene expression in CNTF-treated animals.

Interestingly, rats treated with CNTF have a reduced weight gain as compared to LacZ injected animals. No weight loss was, however, reported with encapsulated cells genetically engineered to produce human CNTF (4-11 ng/day) implanted in the lateral ventricle (Emerich et al., 1996, 1997a) or with the intracerebral administration of recombinant rat CNTF (9.4 $\mu \mathrm{g}$ /day) using an osmotic minipump (Anderson et al., 1996). In contrast, the systemic delivery of CNTF (approximately $8 \mu \mathrm{g} /$ day) in rat pups was associated with muscle wasting (Henderson et al., 1994). This might be due to differences in the sites of administration of CNTF (CNS vs periphery) or in the diffusion of CNTF from the ventricles or in the parenchyma (Kordower et al., 1999a). It has been proposed that CNTFinduced weight loss is the consequence of anorexia caused by a reduction of the hypothalamic appetite stimulating neuropeptide Y (NPY) (Xu et al., 1998; Pu et al., 2000). The intrastriatal injection of CNTF-expressing lentiviral vector may therefore affect NPY- 
producing neurons located in the brain stem and arcuate nucleus of the basal hypothalamus. Inducible lentiviral vectors (Kafri et al., 2000; Gingrich and Roder, 1998) need to be developed to further investigate the dose-dependent neuroprotective effects of $\mathrm{CNTF}$, to perform toxicity studies, and finally to turnoff gene expression in cases of side effects.

Recently, it has been shown that cell death of primary rat striatal cultures transfected with a mutated huntingtin fragment is hampered by the addition of recombinant CNTF (Saudou et al., 1998). This in vitro study suggests, for the first time, that CNTF may not only alter the degeneration of GABAergic neurons in neurotoxin-induced models of HD but also in a genetic model. The lentiviral-mediated administration of CNTF in the striatum of HD transgenic mice (Mangiarini et al., 1996; Reddy et al., 1998; Hodgson et al., 1999; Schilling et al., 1999; Yamamoto et al., 2000) should further establish the potential therapeutic value of this molecule.

\section{ACKNOWLEDGMENTS}

The authors thank Fabienne Pidoux, Maria Rey, Dana Hornfeld and Nathalie Garin for expert technical assistance. This work was supported in part by the Swiss National Science Foundation and the AFM (Association Française contre les Myopathies). Luís Pereira de Almeida is supported by the Portuguese Foundation for Science and Technology (PRAXIS XXI program).

\section{REFERENCES}

Aebischer, P., Pochon, N. A. M., Heyd, B., Déglon, N., Joseph, J.-M., Zurn, A., Baetge, E. E., Hammang, J. P., Goddard, M., Lysaght, M., Kaplan, F., Kato, A. C., Schluep, M., Hirt, L., Regli, F., Porchet, F., \& de Tribolet, N. (1996) Gene therapy for amyotrophic lateral sclerosis (ALS) using a polymer encapsulated xenogenic cell line engineered to secrete hCNTF. Hum. Gene Ther. 7, 851-860.

Anderson, K. D., Panayotatos, N., Corcoran, T. L., Lindsay, R. M., \& Wiegand, S. J. (1996) Ciliary neurotrophic factor protects striatal output neurons in an animal model of Huntington disease. Proc. Natl. Acad. Sci. USA 93, 7346-7351.

Anderson, W. F. (1998) Human gene therapy. Nature 392(Suppl.), $25-30$.

Araujo, D. M., \& Hilt, D. C. (1997) Glial cell line-derived neurotrophic factor attenuates the exitotoxin-induced behavioral and neurochemical deficits in a rodent model of Huntington's disease. Neuroscience 81, 1099-1110.

Asada, H., Ip, N. Y., Pan, L., Razack, N., Parfitt, M. M., \& Plunkett, R. J. (1995) Time course of ciliary neurotrophic factor mRNA expression is coincident with the presence of protoplasmic astrocytes in traumatized rat striatum. J. Neurosci. Res. 40, 22-30.

Bachoud-Lévi, A.-C., Hantraye, P., \& Peschanski, M. (1998) Prospectives for cell and gene therapy in Huntington's disease. Prog. Brain Res. 117, 511-524.
Beal, M. F. (1992) Does impairment of energy metabolism result in exitotoxic neuronal death in neurodegenerative illnesses? Ann. Neurol. 31, 119-130.

Beal, M. F., Kowall, N. W., Ellison, D. W., Mazurek, M. F., Swartz, K. J., \& Martin, J. B. (1986) Replication of the neurochemical characteristics of Huntington's disease by quinolinic acid. Nature 321, 168-171.

Bemelmans, A. P., Horellou, P., Pradier, L., Brunet, I., Colin, P., \& Mallet, J. (1999) Brain-derived neurotrophic factor-mediated protection of striatal neurons in an excitotoxic rat model of Huntington's disease, as demonstrated by adenoviral gene transfer. Hum. Gene Ther. 10, 2987-2997.

Bonni, A., Frank, D. A., Schindler, C., \& Greenberg, M. E. (1993) Characterization of a pathway for ciliary neurotrophic factor signaling to the nucleus. Science 262, 1575-1579.

Bonni, A., Sun, Y., Nadal-Vicens, M., Bhatt, A., Frank, D. A., Rozovsky, I., Stahl, N., Yancopoulos, G. D., \& Greenberg, M. E. (1997) Regulation of gliogenesis in the central nervous system by the JAK-STAT signaling pathway. Science 278, 477-483.

Bensadoun, J.-C., Déglon, N., Tseng, J. L., Ridet, J.-L., Zurn, A. D., \& Aebischer, P. (2000) Lentiviral vectors as a gene delivery system in the mouse midbrain: cellular and behavioural improvements in a 6-OHDA model of Parkinson's disease using GDNF. Exp. Neurol. 164, 15-24.

Blömer, U., Naldini, L., Kafri, T., Trono, D., Verma, I. M., \& Gage, F. H. (1997) Highly efficient and sustained gene transfer in adult neurons with a lentivirus vector. J. Virol. 71, 6641-6649.

Borlongan, C. V., Randall, T. S., Cahill, D. W., \& Sanberg, P. R. (1995) Asymmetrical motor behavior in rats with unilateral striatal excitotoxic lesions as revealed by the elevated body swing test. Brain Res. 676, 231-234.

Buzas, B., Symes, A. J., \& Cox, B. M. (1999) Regulation of nociceptin/orphanin FQ gene expression by neuropoietin cytokines and neurotrophic factors in neurons and astrocytes. J. Neurochem. 72, 1882-1889.

Cisterni, C., Henderson, C. E., Aebischer, P., Pettmann, B., \& Déglon, N. (2000) Efficient gene transfer and expression of biologically active glial cell line-derived neurotrophic factor in rat motoneurons transduced with lentiviral vectors. J. Neurochem. 74, 1820-1828.

Déglon, N., Tseng, J. L., Bensadoun, J.-C., Zurn, A. D., Arsenijevic, Y., Pereira de Almeida, L., Zufferey, R., Trono, D., \& Aebischer, P. (2000) Self-inactivating lentiviral vectors with enhanced transgene expression as potential gene transfer system in Parkinson's disease. Hum. Gene Ther. 11, 179-190.

Dull, T., Zufferey, R., Kelly, M., Mandel, R. J., Nguyen, M., Trono, D., \& Naldini, L. (1998) A third-generation lentivirus vector with a conditional packaging system. J. Virol. 72, 8463-8471.

Ellison, D. W., Kowall, N. W., \& Martin, J. B. (1977) Subset of neurons characterized by the presence of NADPH-diaphorase in substantia innominata. J. Comp. Neurol. 260, 233-245.

Emerich, D. F., Lindner, M. D., Winn, S. R., Chen, E.-Y., Frydel, B. R., \& Kordower, J. H. (1996) Implants of encapsulated human CNTFproducing fibroblasts prevent behavioral deficits and striatal degeneration in a rodent model of Huntington's disease. J. Neurosci. 16, 5168-5181.

Emerich, D. F., Cain, C. K., Greco, C., Saydoff, J. A., Hu, Z. Y., Liu, H., \& Lindner, M. D. (1997a) Cellular delivery of human CNTF prevents motor and cognitive dysfunction in a rodent model of Huntington's disease. Cell Transplant. 6, 249-266.

Emerich, D. F., Winn, S. R., Hantraye, P., Peschanski, M., Chen, E.-Y., Chu, Y., McDermott, P., Baetge, E. E., \& Kordower, J. H. 
(1997b) Protective effect of encapsulated cells producing neurotrophic factor CNTF in a monkey model of Huntington's disease. Nature 386, 395-399.

Fricker, R. A., Annett, L. E., Torres, E. M., \& Dunnett, S. B. (1996) The placement of a striatal ibotenic acid lesion affects skilled forelimb use and the direction of drug-induced rotation. Brain Res. Bull. 41, 409-416.

Gingrich, J. R., \& Roder, J. (1998) Inducible gene expression in the nervous system of transgenic mice. Annu. Rev. Neurosci. 21, 377405.

Gloaguen, I., Costa, P., Demartis, A., Lazzaro, D., Di Marco, A., Graziani, R., Paonessa, G., Chen, F., Rosenblum, C. I., Van der Ploeg, L. H., Cortese, R., Ciliberto, G., \& Laufer, R. (1997) Ciliary neurotrophic factor corrects obesity and diabetes associated with leptin deficiency and resistance. Proc. Natl. Acad. Sci. USA 94, 6456-6461.

Gu, M., Gash, M. T., Mann, V. M., Javoy-Agid, F., Cooper, J. M., \& Schapira, A. H. V. (1996) Mitochondrial defect in Huntington's disease caudate nucleus. Ann. Neurol. 39, 385-389.

Henderson, J. T., Seniuk, N. A., Richardson, P. M., Gauldie, J., \& Roder, J. C. (1994) Systemic administration of ciliary neurotrophic factor induces cachexia in rodents. J. Clin. Invest. 93, 2632-2638.

Hirano, T., Matsuda, T., \& Nakajima, K. (1994) Signal transduction through gp130 that is shared among the receptors for the interleukin 6 related cytokine subfamily. Stem Cells 12, 262-277.

Hodgson, J. G., Agopyan, N., Gutekunst, C.-A., Leavitt, B. R., LePiane, F., Singaraja, R., Smith, D. J., Bissada, N., McCutcheon, K., Nasir, J., Jamot, L., Li, X.-J., Stevens, M. E., Rosemond, E., Roder, J. C., Phillips, A. G., Rubin, E. M., Hersch, S. M., \& Hayden, M. R. (1999) A YAC mouse model for Huntington's disease with fulllength mutant huntingtin, cytoplasmic toxicity, and selective striatal neurodegeneration. Neuron 23, 181-192.

Hottinger, A. F., Azzouz, M., Déglon, N., Aebischer, P., \& Zurn, A. D. (2000) Complete and long-term rescue of lesioned adult motoneurons by lentiviral-mediated expression of glial cell linederived neurotrophic factor in the facial nucleus. J. Neurosci. 20, 5587-5593.

Ip, N. Y., Wiegand, S. J., Morse, J., \& Rudge, J. S. (1993) Injuryinduced regulation of ciliary neurotrophic factor mRNA in the adult rat brain. Eur. J. Neurosci. 5, 25-33.

Johnston, J., \& Power, C. (1999) Productive infection of human peripheral blood mononuclear cells by feline immunodeficiency virus: Implications for vector development. J. Virol. 73, 2491-2498.

Kafri, T., van Praag, H., Gage, F. H., \& Verma, I. M. (2000) Lentiviral vectors: Regulated gene expression. Mol. Ther. 1, 516-521.

Klimatcheva, E., Rosenblatt, J. D., \& Planelles, V. (1999) Lentiviral vectors and gene therapy. Front. Biosci. 4, 481-496.

Kohutnicka, M., Bringas, J., Pivirotto, P., Cunningham, J., Jagust, W., Eberling, J., \& Bankiewicz, K. S. (1999) Convection-enhanced gene transfer of adeno-associated viral vector in Parkinsonian monkeys. Soc. Neurosci. Vol. 25, 294.2.

Kopyov, O. V., Jacques, S., Lieberman, A., Duma, C. M., \& Eagle, K. S. (1998) Safety of intrastriatal neurotransplantation for Huntington's disease patients. Exp. Neurol. 149, 97-108.

Kordower, J. H., Isacson, O., \& Emerich, D. F. (1999a) Cellular delivery of trophic factors for the treatment of Huntington's disease: Is neuroprotection possible? Exp. Neurol. 159, 4-20.

Kordower, J. H., Bloch, J., Ma, S., Chu, Y., Palfi, S., Roitberg, B., Emborg, M., Hantraye, P., Déglon, N., \& Aebischer, P. (1999b) Lentiviral gene transfer to the nonhuman primate brain. Exp. Neurol. 160, 1-16.
Loeb, J. E., Cordier, W. S., Harris, M. E., Weitzman, M. D., \& Hope, T. J. (1999) Enhanced expression of transgenes from adeno-associated virus vectors with the woodchuck hepatitis virus posttranscriptional regulatory element: Implications for gene therapy. Hum. Gene Ther. 10, 2295-2305.

Mangiarini, L., Sathasivam, K., Seller, M., Cozens, B., Harper, A., Hetherington, C., Lawton, M., Trottier, Y., Lehrach, H., Davies, S. W., \& Bates, G. P. (1996) Exon 1 of the HD gene with an expanded CAG repeat is sufficient to cause a progressive neurological phenotype in transgenic mice. Cell 87, 493-506.

Martínez-Serrano, A., \& Björklund, A. (1996) Protection of the neostriatum against excitotoxic damage by neurotrophin-producing, genetically modified neural stem cells. J. Neurosci. 16, 4604-4616.

Mattson, M. P., Lovell, M. A., Furukawa, K., \& Markesbery, W. R. (1995) Neurotrophic factors attenuate glutamate-induced accumulation of peroxides, elevation of intracellular $\mathrm{Ca}^{2+}$ concentration, and neurotoxicity and increase antioxidant enzyme activities in hippocampal neurons. J. Neurochem. 65, 1740-1751.

Mitrophanous, K. A., Yoon, S., Rohll, J. B., Patil, D., Wilkes, F. J., Kim, V. N., Kingsman, S. M., Kingsman, A. J., \& Mazarakis, N. D. (1999) Stable gene transfer to the nervous system using a nonprimate lentiviral vector. Gene Ther. 6, 1808-1818.

Mittoux, V., Joseph, J.-M., Conde, F., Palfi, S., Dautry, C., Poyot, T., Bloch, J., Déglon, N., Ouary, S., Nimchinsky, E. A., Brouillet, E., Hof, P. R., Peschanski, M., Aebischer, P., \& Hantraye, P. (2000) Restoration of cognitive and motor functions with ciliary neurotrophic factor in a primate model of Huntington's disease. Hum. Gene Ther. 11, 1177-1187.

Nakao, N., Grasbon-Frodl, E. M., Widner, H., \& Brundin, P. (1996) Antioxidant treatment protects striatal neurons against excitotoxic insults. Neuroscience 73, 185-200.

Nakao, N., \& Brundin, P. (1997) Effects of alpha-phenyl-tert-butyl nitrone on neuronal survival and motor function following intrastriatal injections of quinolinate or 3-nitropropionic acid. Neuroscience 76, 749-761.

Nakao, N., Ogura, M., Nakai, K., \& Itakura, T. (1999) Embryonic striatal grafts restore neuronal activity of the globus pallidus in a rodent model of Huntington's disease. Neuroscience 88, 469-477.

Naldini, L., Blömer, U., Gallay, P., Ory, D., Mulligan, R., Gage, F. H., Verma, I. M., \& Trono, D. (1996a) In vivo gene delivery and stable transduction of nondividing cells by a lentiviral vector. Science 272, 263-267.

Naldini, L., Blömer, U., Gage, F. H., Trono, D., \& Verma, I. M. (1996b) Efficient transfer, integration, and sustained long-term expression of the transgene in adult rat brains injected with a lentiviral vector. Proc. Natl. Acad. Sci. USA 93, 11382-11388.

Olsen, J. C. (1998) Gene transfer vectors derived from equine infectious anemia virus. Gene Ther. 5, 1481-1487.

Oorschot, D. E. (1996) Total number of neurons in the neostriatum, pallidal, subthalamic, and substantia nigra nuclei of the rat basal ganglia: A stereological study using the Cavalieri and optical disector methods. J. Comp. Neurol. 366, 580-599.

Palfi, S. P., Ferrante, R. J., Brouillet, E., Beal, M. F., Dolan, R., Guyot, M. C., Peschanski, M., \& Hantraye, P. (1996) Chronic 3-nitropropionic acid treatment in baboons replicates the cognitive and motor deficits of Huntington's disease. J. Neurosci. 16, 3019-3025.

Park, F., Ohashi, K., Chiu, W., Naldini, L., \& Kay, M. A. (2000) Efficient lentiviral transduction of liver requires cell cycling in vivo. Nat. Genet. 24, 49-52.

Paterna, J.-C., Moccetti, T., Mura, A., Feldon, J., \& Büeler, H. (2000) Influence of promoter and WHV posttranscriptional regulatory 
element on AAV-mediated transgene expression in the rat brain. Gene Ther. 7, 1304-1311.

Poeschla, E., Gilbert, J., Li, X., Huang, S., Ho, A., \& Wong-Staal, F. (1998) Identification of a human immunodeficiency virus type 2 (HIV-2) encapsidation determinant and transduction of nondividing human cells by HIV-2-based lentivirus vectors. J. Virol. 72, 6527-6536.

Pu, S., Dhillon, H., Moldawer, L. L., Kalra, P. S., \& Kalra, S. P. (2000) Neuropeptide $Y$ counteracts the anorectic and weight reducing effects of ciliary neurotropic factor. J. Neuroendocrinol. 12, 827-832.

Reddy, P. H., Williams, M., Charles, V., Garrett, L., Pike-Buchanan, L., Whetsell, W. O., Miller, G., \& Tagle, D. A. (1998) Behavioral abnormalities and selective neuronal loss in HD transgenic mice expressing mutated full-length HD cDNA. Nat. Genet. 20, 198202.

Romano, G., Pacilio, C., \& Giordano, A. (1999) Gene transfer technology in therapy: Current applications and future goals. Stem Cells 17, 191-202.

Russel, S. J., \& Cosset, F.-L. (1999) Modifying the host range properties of retroviral vectors. J. Gene Med. 1, 300-311.

Saudou, F., Finkbeiner, S., Devys, D., \& Greenberg, M. E. (1998) Huntingtin acts in the nucleus to induce apoptosis but death does not correlate with the formation of intranuclear inclusions. Cell 95, 55-66.

Schilling, G., Becher, M. W., Sharp, A. H., Jinnah, H. A., Duan, K., Kotzuk, J. A., Slunt, H. H., Ratovitski, T., Cooper, J. K., Jenkins, N. A., Copeland, N. G., Price, D. L., Ross, C. A., \& Borchelt, D. R. (1999) Intranuclear inclusions and neuritic aggregates in transgenic mice expressing a mutant N-terminal fragment of huntingtin. Hum. Mol. Genet. 8, 397-407.

Schumacher, J. M., Short, M. P., Hyman, B. T., Breakefield, X. O., \& Isacson, O. (1991) Intracerebral implantation of nerve growth factor-producing fibroblasts protects striatum against neurotoxic levels of excitatory amino acids. Neuroscience 45, 561-570.

Serafini, T. (1999) Of neurons and gene chips. Curr. Opin. Neurobiol. 9, 641-644.

Srinivasakumar, N., Chazal, N., Helga-Maria, C., Prasad, S., Hammarskjöld, M.-L., \& Rekosh, D. (1997) The effect of viral regulatory protein expression on gene delivery by human immunodeficiency virus type 1 vectors produced in stable packaging cell lines. J. Virol. 71, 5841-5848.

St Hillaire, M., Shannon, K., Schumacher, J., Starr, P., Penn, R., VanHorne, C., Isacson, O., \& Fink, S. (1998) Transplantation of fetal porcine striatal cells in Huntington's disease: Preliminary safety and efficacy results. Neurology 50, A80.

Tenenbaum, L., Hamdane, M., Pouzet, M., Avalosse, B., Stathopoulos, A., Jurysta, F., Rosenbaum, C., Hanemann, C. O., Levivier, M.,
\& Velu, T. (1999) Cellular contaminats of adeno-associated virus vector stocks can enhance transduction. Gene Ther. 6, 1045-1053.

The Huntington's Disease Collaborative Research Group (1993) A novel gene containing a trinucleotide repeat that is expanded and unstable on Huntington's disease chromosome. Cell 72, 971-983.

Tseng, J. L., Bruhn, S. L., Zurn, A. D., \& Aebischer, P. (1998) Neurturin protects dopaminergic neurons following medial forebrain bundle axotomy. NeuroReport 9, 1817-1822.

Trono, D. (2000) Lentiviral vectors: Turning a deadly foe into a therapeutic agent. Gene Ther. 7, 20-23.

Verma, I. M., \& Somia, N. (1997) Gene therapy-promises, problems and prospects. Nature 389, 239-242.

Volpe, B. T., Wildmann, J., \& Altar, C. A. (1998) Brain-derived neurotrophic factor prevents the loss of nigral neurons induced by excitotoxic striatal-pallidal lesions. Neuroscience 83, 741-748.

Vonsattel, J. P., \& DiFiglia, M. (1998) Huntington disease. J. Neuropathol. Exp. Neurol. 57, 369-384.

Walther, W., \& Stein, U. (1996) Cell-type-specific and inducible promoters for vectors in gene therapy as an approach for cell targeting. J. Mol. Med. 74, 379-392.

White, S. M., Renda, M., Nam, N.-Y., Klimatcheva, E., Zhu, Y., Fisk, J., Halterman, M., Rimel, B. J., Federoff, H., Pandya, S., Rosenblatt, J. D., \& Planelles, V. (1999) Lentivirus vectors using human and simian immunodeficiency virus elements. J. Virol. 73, 2832-2840.

Xu, B., Dube, M. G., Kalra, P. S., Farmerie, W. G., Kaibara, A., Moldawer, L. L., Martin, D., \& Kalra, S. P. (1998) Anorectic effects of the cytokine, ciliary neurotrophic factor, are mediated by hypothalamic neuropeptide Y: Comparison with leptin. Endocrinol. 139, 466-473.

Yamamoto, A., Lucas, J. J., \& Hen, R. (2000) Reversal of neuropathology and motor dysfunction in a conditional model of Huntington's disease. Cell 101, 57-66.

Zennou, V., Petit, C., Guetard, D., Nerhbass, U., Montagnier, L., \& Charneau, P. (2000) HIV-1 genome nuclear import is mediated by a central DNA flap. Cell 101, 173-185.

Zufferey, R., Nagy, D., Mandel, R. J., Naldini, L., \& Trono, D. (1997) Multiply attenuated lentiviral vector achieves efficient gene delivery in vivo. Nat. Biotechnol. 15, 871-875.

Zufferey, R., Donello, J. E., Trono, D., \& Hope, T. J. (1999) Woodschuck hepatitis virus posttranscriptional regulatory element enhances expression of transgenes delivered by retroviral vectors. J. Virol. 73, 2886-2892.

Zurn, A. D., Baetge, E. E., Hammang, J. P., Tan, S. A., \& Aebischer, P. (1994) Glial cell line-derived neurotrophic factor (GDNF), a new neurotrophic for motoneurons. NeuroReport 6, 113-118.

Zurn, A. D., \& Werren, F. (1994) Development of CNS cholinergic neurons in vitro: Selective effects of CNTF and LIF on neurons from mesencephalic cranial motor nuclei. Dev. Biol. 163, 309-315. 